\title{
GRAP wt Allele
}

National Cancer Institute

\section{Source}

National Cancer Institute. GRAP wt Allele. NCI Thesaurus. Code C52387.

Human GRAP wild-type allele is located in the vicinity of $17 p 11.2$ and is approximately 26

$\mathrm{kb}$ in length. This allele, which encodes GRB2-related adaptor protein, is involved in the regulation of receptor tyrosine kinase/Ras-dependent signal transduction pathways. 